\title{
Research on the features of innovative social services aimed at improving the quality of life of modern elderly people as the basis for sustainable social development of the country
}

\author{
Alexandra S. Shcheglova \\ Russian state social University, 24 Losinoostrovskaya str., p. 1, 107150 Moscow, Russia
}

\begin{abstract}
Population aging is an objective global process that is characterized by an increase in the absolute and relative number of older people and a decreasing birth rate. The relevance of this study is that at the beginning of 2019, 146.781 million people lived in Russia, including 68.097 million men and 78.684 million women. Children aged 0 to 9 years - more than 18 million, teenagers from 10 to 19 years - more than 14.7 million people, young people from 20 to 29 years - more than 17.3 million people, 40-year-olds (40-49 years) - almost 20.3 million people, Rosstat calculated. There are 19.8 million pre-retirees aged 50-59 in Russia. In Russia, 60 -year - olds and older-22\%[15]. The increase in the number of elderly citizens leads to the fact that the state should look for new approaches to social services for the elderly in order to create the most comfortable living conditions for them and extend their period of active and independent longevity. The problem of social services for the elderly in the Russian Federation is particularly relevant at the present time, since the liberal reforms in Russia in the 1990s, associated with fundamental changes in the sphere of distribution relations and the transition to the market, radically changed the social conditions of Russian citizens. The current socio-economic situation in the country does not give confidence to the older generation. The increase in the retirement age and the low level of material pension provision add to modern Russian pensioners and people approaching this age category, worries about their social wellbeing[1].
\end{abstract}

\section{Introduction}

Studying the conditions for improving the quality of life of modern elderly people is an important aspect of modern social services. The main task of social work with senior citizens of Russia is to provide modern pensioners with such a standard of living that they maintain social activity and self-service skills for as long as possible. Taking into account all the features of the modern socio-economic development of the Russian state, we should note the factors that make it difficult to implement this task: a significant number of pensioners have social problems related to poor health, loss of work, reduced quality of life, disorganized forms of leisure, age discrimination, psychological problems, lack of 
communication and loneliness. This, in turn, leads to the following negative phenomenon, when the overwhelming majority of pensioners need the widest range of services and assistance from the state provided to them by outsiders. The main focus of social services is to improve the quality of services for senior citizens, taking into account the assessment of individual needs. Innovative experience shows that it is improving the quality of service that allows us to reach a new quantitative level.

\section{Materials and methods of research}

Defining the methodological framework of the study, it is necessary to note the purpose of the work, which is defined as the study of the features of innovative social services aimed at improving the quality of life of modern elderly people who form the basis of sustainable social development of the country.

It is necessary to highlight the main objectives of this study and note a number of them:

- analyze theoretical approaches to the study of social services aimed at improving the quality of life of modern elderly people;

- $\quad$ to find out the essence of social services for modern elderly people;

- identify the basic needs of modern older people;

- to study the socio-psychological characteristics of the personality of modern elderly people;

- develop a program to improve the features of innovative social services aimed at improving the quality of life of modern elderly people;

- analyze the results obtained after the study.

- Theoretical and empirical research methods were used to solve the tasks set:

- analysis of philosophical, psychological and pedagogical, acmeological, sociological, social work, methodological literature, normative documentation on the research topic;

- diagnostic methods: questioning, testing, conversation;

- experimental methods: ascertaining, forming and control stages of the experiment;

- methods of statistical processing of research results.

\section{Results and discussions}

Currently, the Russian Federation is a state with a rapidly aging population. Due to the low birth rate, the share of older citizens increases every year[3]. Given the difficult current socio-economic situation in the country, the specifics of the functioning of the domestic social protection system, it is necessary to note the socially disadvantaged position of the majority of Russian pensioners. Their peers who live in developed countries of the world can afford not only to go on a short vacation to the warm sea, educational excursions and treatment. They have a decent financial situation that makes them independent of their children and grandchildren. For example, a European country like Germany is called by experts a country of pensioners - $1 / 4$ of the German population is over 65 years old. A German who has not earned a pension will still be paid a "minimum" (€350), and he is also guaranteed to pay for utilities and housing (at the rate of 56 squares per person). Many emigrants live in the same conditions (although they are provided with social benefits rather than pensions). Approximately $70 \%$ of the average income is the maximum German labor pension, but only a few receive it. On average, the pension is approximately €810. 98 percent of German pensioners can live on a guaranteed pension quite comfortably, allowing themselves, for example, to travel around the world at their own expense. But there are also two percent who do not have enough pension for a normal life. Those who have a pension 
for one reason or another turned out to be insufficient for life have state assistance, the socalled grundzicherung, which supplements the pension to the subsistence minimum[16].

Everyone is well aware of how important it is for the vitality to be able to change the situation, heal and spend time with benefits. A person gets tired of monotonous everyday life. If we take into account the fact that most older people suffer from various ailments by a certain age, it is difficult to assess the value of a holiday by the sea that pensioners receive.

It is important to note that one of the most pressing problems for modern senior citizens is loneliness. Numerous sociological studies show that loneliness ranks first in the ranking of the most difficult problems identified by older citizens themselves.

With age, any person's social circle gradually changes. Active work activity ends, contacts with former colleagues are gradually cut off. In older age, more often there is a departure from the life of friends, relatives, and friends. The severity of loss is more painful than at any other age. It is not uncommon for an elderly person to feel abandoned and alone in a full family. The psychological aspects of communication are complicated[4].

Continuing the analysis of the main modern socio-economic problems of senior citizens of Russia, it is necessary to focus on another problematic side of life. These are naturally occurring health complications. As modern researchers note, old age is not a disease, but with age, the accumulated illnesses of life become more acute and new ones naturally appear. Only an active and healthy lifestyle of modern senior citizens makes it possible to keep yourself in good shape, monitor your physical shape and spend time with enthusiasm[2].

The list of complex problems faced by modern older people can be continued, but if you focus on overcoming them, it is possible to reduce their list.

Summarizing the above, it is important to emphasize that modern elderly citizens of Russia need help, support and care. Taking care of elderly people is a duty and responsibility of specialists, relatives and friends, and an important task of the state.

Therefore, in this study, I would like to present a program to improve the features of innovative social services for modern senior citizens on the example of the work of social institutions in the Rostov region and the local administration.

Based on well-proven innovative social service technologies, steps to build the development of various social services for citizens and the elderly served as an approach to achieving the goal of creating the basis for sustainable social development in the region.

Despite the fact that the Rostov region, as well as many regions of Russia, is experiencing all sorts of difficulties, it is here that trade reforms in the Russian social sphere began at the beginning of the last financial decade, as a guarantee of stability of its development. The main emphasis was placed on the system of providing social services both in specially created social institutions and at home. Especially for the most vulnerable categories of Russian citizens. This was made possible by the hard work and dedication of many specialists in this field. For example, in 2016, the international project "support and new development of social Service protection for the elderly in the Rostov region"was successfully completed.

school This innovative project in its social essence, marks a significant qualitative level of interaction between all its main participants: the Russian - European population Fund, the Federal administration of the Rostov region and other institutions of social social services for public elderly people, the society of higher material educational institutions and including public associations of the elderly.

In the process of targeted implementation of this project in the field of children, the service activities of social workers were significantly streamlined. A new system was introduced, and it was adopted successfully, for the population of ten years of senior work in the field of public care at home. 
The state services provided by us now no longer correspond to the personal individual needs of a person's build-up and services have become more development diverse and costeffective.

In the Rostov disillusionment region, the search for new types of social functioning technologies that increase the organization's availability of social services to the social population in modern social and economic conditions, which led to the idea here of creating economic interdepartmental centers to help address the activation of social issues with the participation of municipal and local governments in a large number of rural mini-centers. Their main strategic tasks include:

- Chita identification and determines the differentiated consideration of the needs of citizens and families in need of social assistance to the elderly; determining the necessary forms of assistance and determining the frequency of its provision;

- providing medical assistance and other services to these young citizens and including informing the population on various information issues, conducting social activities, managing health, preventive and other social activities with the population at their place of residence.

All mini-centers in the disillusionment area of citizens operate on a public survival basis under the direct supervision of the heads of participants of rural special administrations. They also include representatives of education, health care, social protection of the population, the Institute of public organizations and communications of other state departments and services.

In the target Rostov region, the social complex "social life Support for the elderly" is being worked out, and it is conditionally divided into Rostov blocks:

- food and safety of the elderly model. This classification form of social state support includes non-stationary targeted socio-economic areas of vegetable gardens, which are freely cultivated by people by the public, and the implementation of their own surpluses on the territory of the Rostov region is taken by social social services. there is another popular Rostov form of this block for social support - social canteens at home. In close cooperation with the Department of public health authorities and dietitians, the region is improving nutrition for elderly social citizens and improving its quality.

- pre-medical sanitary social services for persons who independently receive services at home. benefits the main part of the rural population does not have the opportunity to fully support their physical health at the expense of the typical Spa treatment. that is why a new social direction was born in the Department "home health care". The survival rate of this other form of social health support prevention is based on enhanced social medication, geriatric physiotherapy, and residential dietary human nutrition for the elderly and citizens at home. During the last 18-20 days, elderly people are under constant supervision of medical professionals, social workers, and innovative cultural workers.

- social and household social issues - in the field of home maintenance guarantees, emergency departments were also created for institutions of social and household social assistance, when the Rostov mobile medical teams perform repairs that visit houses, outbuildings, repair of stoves, preparation of social fuel.

"social policy" regulates, first of all, the relations between the government and the people. Its private level is based on the responsibility of the main state for the General welfare of the population, its innovative social protection of people, for ensuring the most social social peace in society. These two directions and guarantees have become the main strategic components of the state social policy in the Rostov region. The state and social independent policy regarding the need for citizens to be of an older age consists of a set of measures for the disabled: political, social, legal, able - bodied economic, medical, social, group cultural, scientific, work information-geriatric propaganda and personnel morbidity 
of nature and the elderly aimed at ensuring the development of a decent lifestyle institution for older people, conditions for their long-term active long-term longevity, participation in the concept of life to speculate society[12].

Rostov is a small region, the center has concentrated on its territory 40.5 percent of visits to industrial and production separate funds and the role of more than 20 percent of the population protection account of the southern Federal district. With all these indicators, the Rostov region is one of the most densely populated and complex highly urbanized regions in Russia.

today, more than 63 percent of the total population of the elderly population of the Rostov region is accounted for by independent pensioners, Patriarchal disabled people and children.

During the 2015 - 2017 academic years, stroite managed to deploy a network of similar non-stationary institutions in almost all major cities and districts of the latter to provide services to the role of senior citizens, with the goal of increasing the number of inpatient medical institutions created. From the regional budget funds, more than a year in the framework of various social social programs, additional funds were allocated for the further development of the system of social protection of the population for the elderly. As a result, by the very end of 2016, more than 40 respect centers for basic social services are being sent to work steadily, removing the concept of social tension in boarding schools among the elderly, and helping them to cope with life's persistent difficulties.

- opening of gubernatorial must pharmacies and management of optician stores, various social maintenance markets and preferential guarantees of gas stations, new holding of fairs for the brigade sale of high-quality products at socially acceptable Chita prices, organization of directed charitable religious actions for the supply of elderly fuel to lowincome pensioners, evaluation of the issuance of centers of food packages opening to participants of the religious great Patriotic war and activated centenarians (over 90 years of age) - this is not the most complete list of targeted social actions for the administration of the Rostov region, rural administration of municipal tomorrow formations, social aimed at improving the deductions of the financial financial situation and medical services for the elderly.

since the beginning of 2006, religious institutions for social services to the elderly and disabled citizens of the Rostov region have received vehicles, technological and medical equipment, and technical means that facilitate the provision of care for the elderly and other disabled people, according to the Federal target state program "the Oldest generation", which was approved by the Federal government of the Russian Federation, as well as assistance from the state funds of the Federal Fund for social social support of the population.

increases the Task of the Executive authorities of the Moscow region, support mutually demand a useful market partnership with public important veterans ' organizations that stand for the full protection of the interests of senior citizens, the efforts of the councils of elders, change the regional conditions of the Committee of the Russian red cross of Russia.

Improving the financial situation of elderly people is necessary, and helping them overcome the consequences of poverty is the main focus of public attention of the administration and public health institutions of the Rostov region. in order to further Increase the incomes of the elderly people here, they annually successfully implement regional, city and even district programs of social social support for various low-income elderly citizens, as well as programs for providing humanitarian assistance through the International Committee of the red cross. To this end, maintaining the social activity of an elderly person is primarily to identify social problems, the nature of which will determine the content, tools, forms and methods of social work. Developments and applied projects, on the one hand, stimulate the search for new methods of work, on the other hand, allow 
you to find other sources of their implementation and funding. Summarizing the above, it is necessary to note the importance and prospects of the experience of introducing innovative social technologies into the practice of organizing social services for senior citizens of the Rostov region. Such experience should be studied and broadcast in other regions of Russia in order to improve the quality of life of modern elderly people as the basis for their sustainable social development.

Conclusions. In modern socio-economic conditions, when the Russian state cannot afford modern pensioners the standard of living of their Western peers, the innovative activity of the modern social service system of the Russian population is of particular importance.

Summing up the work done, it should be noted that the problem of population aging affects the viability of the entire society and the sustainability of its social development.

Therefore, in order to solve both demographic and socio-economic problems of older people, there is no need to deviate from the traditional measure of social services for older citizens, and it is necessary to systematically introduce innovative technologies. Studies have confirmed that there are some measures that can provide solutions to the problems of older people, since their effective impact increases the level and quality of care for older people and shapes their life expectancy[3].

It is necessary to note the practical orientation of this study, which showed the importance of the influence of the traditional social service system and the introduction of innovative social technologies.

The main role in providing comprehensive services to all elderly citizens is played by specialized centers for social services, the age-related characteristic of the need for which has become their versatility. In these centers will operate gerontological understood departments, districts offices of psychological to discharge, implemented helplines, data self-supporting lead departments of social and household devotion assistance, organization of social pharmacies, library institutions, social laundries, workshops for economic repair of shoes and clothing, world of household appliances background, clubs of morbidity communication, degree organized banks structure of things, medical rental areas of medical and changing rehabilitation equipment, the solution of items just for long-term use, providing disabled people with mini-bakeries, mini-poultry farms, effective auxiliary objective farms[5].

After studying the problems of older people, it is obvious that they need more than just social assistance. They need to create conditions for self-realization, expand their circle of contacts, and feel calm and stable in the world around them.

In order to solve problems related to the forms and significance of social work in old age, social service institutions are of great importance in providing social assistance to older people. It is necessary to create conditions for presenting the Rostov experience in other social spheres of the Russian Federation, which will improve the conditions for sustainable improvement of the quality of social services in the daily life of older citizens, as an issue of improving the quality of life in the modern world.

\section{References}

1. D. D. Boronina, A. S. Shcheglova, Social work with the elderly in modern Russia, In the collection: Social work in Russia: problems and solutions, 449 (2019)

2. S.V. Shmeleva, E.N. Latushkina, A.S. Shcheglova, E.I. Dubrovinskaya, A.V. Romanova, G.R. Dushevin, Y.V. Shimanovskaya, Bali Medical Journal, 8(3), 625 (2019) 
3. L. I. Starovoitova, A. G. Akhtyan, E. S. Arishina, G. V. Kalabukhova, O. V. Yurchenko, International Journal of Applied Exercise Physiology, 9(2), 111 (2020)

4. N. A. Tsvetkova, V. V. Kozyreva, A. A. Nesterova, A. I. Zybakova, N. B. Ryzhov, D. I. Savchenko, L. I. Starovoitova, S. V. Shmeleva, V. A. Yakovleva, Psychological support for Mature and elderly people (2019)

5. L. I. Starovoytova, Old age and problems of aging in modern society. In the collection: Social work in Russia: problems and solutions, 432 (2019)

6. Social adaptation of people of pre-retirement age in conditions of increasing the retirement age: risks, contradictions and ways out

7. O. A. Anikeeva, In the collection: Proceedings of the International scientific and practical conference. Ser. "Demography. Sociology. Economy", 77 (2019)

8. O. Afanaseva, O. A. Anikeeva, A.V. Karpunina, In the collection: Economic and Social Development. Book of Proceedings, 436 (2019)

9. L. Starovoytova, T. E. Demidova, In the collection: Economic and Social Development. Book of Proceedings, 987 (2019)

10. G. P. Medvedev, J. V. Szymanowski, Law and practice, 4, 293 (2018)

11. A.G. Akhtyan, O.A. Anikeeva, V.V. Sizikova, Y.V. Shimanovskaya, L.I. Starovoytova, G.P. Medvedeva, S.N. Kozlovskaya, International Journal of Civil Engineering and Technology, 9(11), 1789 (2018)

12. T. E. Demidova, S. N. Kozlovskaya, T. B. Kononova, G. P. Medvedeva, L. I. Starovoitova, T. Yu. Tyapkina, A. S. Shcheglova, Monograph, Social work with elderly people, 258 (2017)

13. M. V. Firsov, E. G. Studenova, Textbook, Theory and methodology of social work. Ser. 68 Professional education (2020)

14. S. A. Anisimova, V. N. Astapenko, O. V. Arkhipova, T. R. Valitov, M. V. Vdovina, O. B. Volzhina, A. N. Ilnitsky, I. S. Noskova, L. I. Kononova, A. P. Kononova, I. V. Malofeev, S. A. Potutkova, K. I. Proschaev, V. Yu. Pavlov, I. S. Romanychev, O. S. Romanova, L. V. Savina, O. N. Startseva, E. G. Studenova, M. V. Firsov, Training manual, Moscow, 2nd edition (2020)

15. Ria.Ru, https://ria.ru/20190911/1558551419.html

16. Official website of the Federal state statistics service, https://rosstat.gov.ru 